\title{
The Global Economy After the End of Capital Scarcity: A Utopian Proposal
}

\begin{abstract}
Extrapolating from List (Das nationale System der politischen Ökonomie. Cotta, Stuttgart, 1841), we explain the paradox of China: A poor country can experience tumultuous growth precisely by exporting more capital on balance than it imports. More growth can be created in developing countries by their running current account surpluses vis-à-vis the OECD plus China region. Public debt in the OECD plus China region would have then to be managed in such a way that full employment is preserved despite the current account deficit. Such a strategy would be beneficial for both groups of countries. For the time being, this is a utopian proposal. Realizing it would mean yet another restructuring, in addition to that associated with digitalization. The opposition of those who could lose their jobs as a result will ensure that this sort of reorientation of global trade policy will remain politically unfeasible for a long time still.
\end{abstract}

\subsection{From Fairy Tale to Political Economy in Ten Years}

Written in 1836 :

They tell a tale in old Cologne

of little elves in days long gone,

when weary workers, should they please,

could laze about and take their ease.

And then by night -

oh, what a sight!

The little elves came chattering,

hustling, bustling, clattering. 
They rubbed and they scrubbed, they swept, washed and scurried, they cleaned and they hurried to finish the work, and before you knew it, whatever there was to be done, they'd do it!

First stanza of The Elves of Cologne.

Poem by August Kopisch (translation by Anthea Bell)

Written in 1841:

Friedrich List's book The National System of Political Economy.

Written in 1846:

For as soon as the distribution of labour comes into being, each man has a particular, exclusive sphere of activity, which is forced upon him and from which he cannot escape. He is a hunter, a fisherman, a herdsman, or a critical critic, and must remain so if he does not want to lose his means of livelihood; while in communist society, where nobody has one exclusive sphere of activity but each can become accomplished in any branch he wishes, society regulates the general production and thus makes it possible for me to do one thing today and another tomorrow, to hunt in the morning, fish in the afternoon, rear cattle in the evening, criticise after dinner, just as I have a mind, without ever becoming hunter, fisherman, herdsman or critic. Karl Marx and Friedrich Engels, The German Ideology.

It was in 1836 that the German poet August Kopisch (1998 [1836]) composed his lyrical apotheosis of the magical elves of Cologne from olden days. A mere ten years later, Karl Marx and Friedrich Engels penned their famous passage expressing similar sentiments, but now in the guise of political economy and a vision of the future. Friedrich List's work on the economic present, The National System of Political Economy, came into being exactly halfway along this path from the past into the future. In it, the author placed Germany, as well as other countries like France and the USA, on the middle level of three levels of economic development. According to List, Great Britain, the most advanced economy of the time, was on the third and highest level of development. On his account, other more backward countries, like Russia, for example, were on the first level.

For List, the free trade program advocated by the British classical school was suitable for the lowest and highest levels, but not for the second level in between them. In a way, List's levels correspond to the division into "developing countries," 
"emerging economies," and "rich countries" that is customary today. In 1841, politically fragmented Germany and the USA were what we now call "emerging economies." For the emerging economies of his time, List recommended placing protective tariffs on goods produced by the manufacturing industry of the third stage countries.

List justifies this different treatment of the different levels by his theory of what he called the "productive powers" of a national economy. These productive powers of agricultural production or manufacturing are influenced by the institutional conditions of each country. Now, List sees a crucial difference between the productive powers of agriculture and those of manufacturing. An important part of the idea of "productive powers" was later taken over by mainstream neoclassical theory in the concept of positive externalities. In List's view, these positive externalities are, above all, to be observed in manufacturing and less so in agriculture.

Among other things, the development of the "productive powers" in an emerging economy also involves learning from the rich countries: at the time, then, learning from Great Britain. In the case of Germany industry, part of this learning from British industry later took place by way of activities that could be classified as "industrial espionage."

According to List, without import barriers, it is hard for the nascent manufacturing sector of an industrializing country to compete with the mature manufacturing sector of a rich country. As a result, the economic potential of positive externalities in the industrializing country does not get developed or at least not sufficiently developed. By using import tariffs to make manufactured goods from the rich countries more expensive, an industrializing country can make it easier for domestic manufacturing to develop and thus take advantage of the positive externalities and economies of scale of the manufacturing sector.

Following List, mainstream economics refers to this as the process of a country's "industrial education." The argument for "educational" tariffs of this sort is recognized in trade theory-under the name of the "infant industry argument." Defenders of free trade warn against putting too much weight on them, however. They rightly point out that import tariffs can also be misused to protect inefficient domestic production from international competition - and to do so precisely at the expense of overall economic development and the restructuring that goes with it. The ossification of existing structures as a result of import tariffs has to be weighed against their function as stimulant for emerging industries with positive externalities.

Historical experience with such a policy of protective tariffs is mixed. There is reason to think that it ultimately harmed development in Latin America, but benefited development in East Asia. Apart from one exception, it is not our intention to discuss these different experiences here. We want rather to continue to tease out the connections between trade policy and our thesis of the negative natural rate of interest. With this goal in mind, we make use of the - chronological-embedding of Friedrich List's theory among the backward- and forward-looking utopias of a world without the toil and drudgery of production. By way of our theory of the negative natural rate, we want to transform this embedding from a purely 
chronological embedding into a causal one. We are aware that, in political-economic terms, we will thus be moving on utopian terrain.

However, this sort of thought experiment- this sort of experiment in utopian thinking - can also help us to understand the phenomenon of the negative natural rate somewhat better.

\subsection{The End of Capital Scarcity is Not the End of Time Scarcity}

Many people moan about the lack of time, and they also moan about the lack of interest income. At first sight, this seems paradoxical: As we have shown, low interest rates are, after all, a consequence of the fact that we live in an age in which capital - from the perspective of the global economy - is no longer scarce. But if in the Böhm-Bawerkian approach that we have adopted here, capital is basically time, then how can capital be abundant, but time extremely scarce?

The answer lies in the existence of a monetary economy with a system of credit. In such an economy, saving and investment diverge. Inasmuch as they lend, individual economic actors can save without investing. And, inasmuch as they borrow, they can invest without saving. Expressed in terms of stock variables, the individual economic actor's real assets are not equivalent to his or her net wealth. The latter can be greater or smaller than the former. Thus, when we speak of the end of capital scarcity, what we mean is that in terms of the global economy (or, in our analysis, the OECD plus China region), privately desired wealth is greater than productively usable real assets even at a real interest rate of zero. A still greater time gap between the original inputs of labor and land, on the one hand, and the outputs in the form of consumer goods, on the other, does not lead to any greater productivity of the production process.

But scarcity of time is something like an anthropological constant. People do a great deal to increase their life expectancy: to prolong their lives. This is one of the forms taken by the fundamental scarcity of time. And, together with progress in medicine and hygiene, it is in no small measure due to peoples' desire to have more time that life expectancy has increased all over the world and in all likelihood will continue to increase. But not even an increased lifespan, and not even the time that has been gained thanks to it, has led to a diminution in the subjective perception of time scarcity. The perception of time scarcity is perhaps even greater today than in earlier times (this is to say, than in earlier times of peace). Diogenes has moved further and further away from us. This may in no small part be due to the fact that the possibilities for communication transcending spatial distances have increased so much today. The potential for contact with other people and groups of people is thus far greater than it was before. The scarce factor in making use of this potential is just one's own time. This applies for private and professional activities alike.

And it is precisely this urge to have more time, this desire to live longer, that is one of the reasons why capital is no longer scarce, as we have shown in detail in Chaps. 1 and 3 on wealth and desired wealth. 
But the divergence between privately desired wealth and economically productive real assets offers an opportunity to accommodate the desire for more time to an even greater extent than has been understood up to now. According to our analysis, under conditions of full employment, this divergence is bridged over by the state, as the only legitimate "Ponzi" scheme operator, having negative net wealth. It thus allows private net wealth to be greater than economically productive real assets. But public debt (as a stock) on which only minimal interest is paid creates the possibility that people will increasingly not want to and not have to work as much for money, that they will thus have more leisure time and hence their private time budget will be greater, and that hence the scarcity of their own time will diminish.

In the following, we will connect this idea to List's idea of the positive externalities of production in emerging economies. We will thus get closer to the utopia of the elves of Cologne. Is the fairy tale a model for the world of the future?

\subsection{The Chinese Economic Miracle}

The discovery of the "saving glut" by Bernanke (2005) and others occurred as a reaction to the hardly orthodox phenomenon of massive capital exports on the part of a then developing country: China. And these capital exports were part of a historical process that can be called the "Chinese economic miracle." In 1980, three-quarters of China's population still lived in absolute poverty. Today, just forty years later, China's per capita income measured on the basis of purchasing power parity is more than a third of that of Germany. In light of its considerably larger population, China is thus a country whose national product is roughly equal to that of the USA. In military and diplomatic terms, China is already regarded as a world power.

These two facts, Chinese capital exports and the tumultuous growth of its national product, are causally linked. It is precisely because of its successful export industries that Chinese productivity was able to increase so rapidly. What China has been striving for since 1980 with its economic reforms is to learn from the West. The (partial) introduction of a market economy served this purpose. And by exporting, Chinese firms learned the business practices that had come to prevail in the rich countries by being successful within the framework of a stable legal and property order.

Anyone who wants to sell successfully in a Western market economy must provide his or her customers, firstly, with goods of satisfactory quality at, secondly, competitive prices and, thirdly, must be able to deliver the goods on time. In the West, sales normally do not happen by bribing the customer's buyer. In traditional societies, the "virtues" of the market economy that we have mentioned here are for the most part only to be found occasionally and often only as rare exceptions. The individualism of modern market societies is scorned. What counts is solidarity in the family: in the clan to which you belong and into which you were born. The duty of 
loyalty toward the group makes it difficult to break from tradition like a Schumpeterian entrepreneur. Margins are high and price competition is to an overwhelming extent unwanted. Small, inefficient firms are not the exception, but the rule.

China had already been "modernized" by Communist rule after 1948. Medical care improved greatly. The "one child policy" created a good demographic basis for per capita economic growth. But the "Great Leap Forward" and the ensuing Cultural Revolution led the country into a dead end, resulting in millions of people dying of starvation. But Mao Zedong could not destroy the industriousness of the Chinese people, despite all his efforts. This industriousness went "underground" during the Cultural Revolution. When niches of private economic activity were introduced on the agricultural collectives at the start of the reforms pursued under the leadership of Deng Xiaoping, agricultural yields soared. The possibility to study at schools and universities again and to obtain professional qualifications was eagerly used and quickly bore fruit. The initial success encouraged the political leadership to go further with market reforms. The know-how of the Chinese minorities in the neighboring capitalist countries and of Taiwan's predominantly Chinese population was also extensively used.

"Learn from your customer" is a promising business motto in all countries. But it is especially apt when the society of which your customer forms part is far more prosperous and far more productive than your own. And this was the situation in which Chinese firms found themselves after 1980. For China, it was a stroke of luck that free international trade was the prevailing ideal in the Western world. As a result, borders were relatively open for Chinese goods. And thus China was able to learn from its customers in a big way.

We do not want here to sing the praises of China or of Western China policy. There are also, needless to say, dark sides to this cohabitation between democrat countries and a large country with a one-party state. China's rise left not only winners in its wake in the West, but also, of course, losers. The 2016 election of Donald Trump as president in the USA and the referendum vote for Brexit in the UK can be attributed, among other things, to the votes of such losers in the process of globalization. And China's rise increased their number. For it accelerated restructuring in the Western economies. And there is no such thing as growth without losers.

Overall, however, the Western economies have benefited from China's success. Labor productivity in the West increased as low-skilled jobs were eliminated and migrated to China, while, at the same time, being replaced by more demanding, better paid jobs at home. There is no doubt that Germany has been one of the biggest winners in this process of restructuring. It should not be forgotten, moreover, that capital exports from China have lowered interest rates on the global market - and that they have done so with constant employment and rising average wages in the West. 


\subsection{Friedrich List and the Chinese Economic Miracle}

Friedrich List fought for German protective tariffs on British industrial goods, so that German industry could undergo a learning process and develop positive externalities. Germany's manufacturing industry took advantage of these opportunities during the nineteenth century and by the end of the century was the equal of Great Britain's. Learning from Great Britain was the order of the day on the Continent at the time. Kaiser Franz Joseph's wife Elisabeth of Austria (better known as "Sissi") had Carl Menger appointed as the tutor of Crown Prince Rudolf. The latter traveled around Great Britain with Menger to familiarize himself with the world's leading economic power and to learn from it (Hamann 1978). After the Meiji Revolution and the associated opening toward the West, Japan also experienced an economic upswing based on learning from the more advanced countries. Friedrich List's ideas also provided inspiration for the Japanese economic policy of the time.

There are thus parallels in economic history to the Chinese economic miracle of the recent past.

If we consider the overall process of all the historical experiments à la List, there is no doubt that they have contributed to accelerating global economic growth while, at the same time, distributing global wealth more evenly. If, as a result of this overall process, East Asia, including China, has caught up with Europe and North America today, then this has both increased global prosperityand distributed it more evenly.

And, on balance, the West, i.e., Europe and North America, have benefited from this process. East Asia supplies the West with goods that are of the same quality, but cheaper. The material standard of living in the Western world has risen thanks to the fact that global trade has mobilized a large number of workers from East Asia to produce consumer and capital goods for the West. And the latter have been paid for with the products of workers in the West, whose capacities would otherwise have been tied up producing less valuable products for the domestic market.

Considering the mutual benefit that both the Western world and the up-and-coming East Asian countries have derived from globalization, we cannot help but ask whether this lesson of economic history should be used so that the rest of the world can also benefit from Listian policies of the same sort. This is the question to which we will turn now.

\subsection{A Two-Country Thought Experiment}

In trade theory, issues of a certain complexity are often first thought through using a two-country model. This is the method that we will use here. We thus divide the world into two regions: the "North" and the "South." The North consists of the economic area that is the special focus of our book: the OECD countries plus China. The South comprises the rest of the world. We now treat these two regions as two 
countries, each with its own single currency. We call the North's currency the "dollar" and the South's currency the "rupee."

Let $X$ be the South's trade surplus, expressed as a percentage of domestic consumption. If $X=0$, then the current accounts of both countries are balanced. If $X>0$, then the South exports more than it imports; if $X<0$, then the South imports more than it exports. In the spirit of the theory of Friedrich List, we now stipulate that there is a positive correlation between the growth rate $g$ of the South's national product and the South's trade surplus $X$. Let $X$ be the independent variable here and $g$ the dependent variable: The growth-promoting "learning" of the Southern "student" from the Northern "teacher" is all the more successful, the more the South focuses on exporting to the North. This is precisely the lesson of the economic history of East Asia since the Second World War and especially of China since Deng Xiaoping's pragmatic turn. Figure 12.1 depicts this relationship. For reasons that will become clear below, we turn the dependent variable $g$ upside down: A higher $g$ is below a lower $g$.

We now add a second functional relationship to this first one: viz. that between the dollar/rupee exchange rate $w$ and the South's trade surplus $X$. The weaker the rupee is in real terms relative to the dollar, the more competitive the South is and the greater is its trade surplus. This causal relationship is represented in Fig. 12.2.

Note that in Fig. 12.2, the independent variable $w$ is plotted on the vertical axis and the dependent variable $X$ on the horizontal axis.

The third causal relationship concerns the North. It consists of the exchange rate $w$ and the public debt ratio $D$ that is required to achieve full employment in the North. The higher the value of the dollar in real terms against the rupee, i.e., the higher $w$ is, the more competitive is the South and the less competitive is the North. The North's public debt must then be all the higher to allow for full employment. In other words: If the real interest rate is close to zero with stable prices and hence cannot fall any further, then the more capital from the South there is on the Northern capital market, i.e., the stronger the effect of Bernanke's "saving glut," the

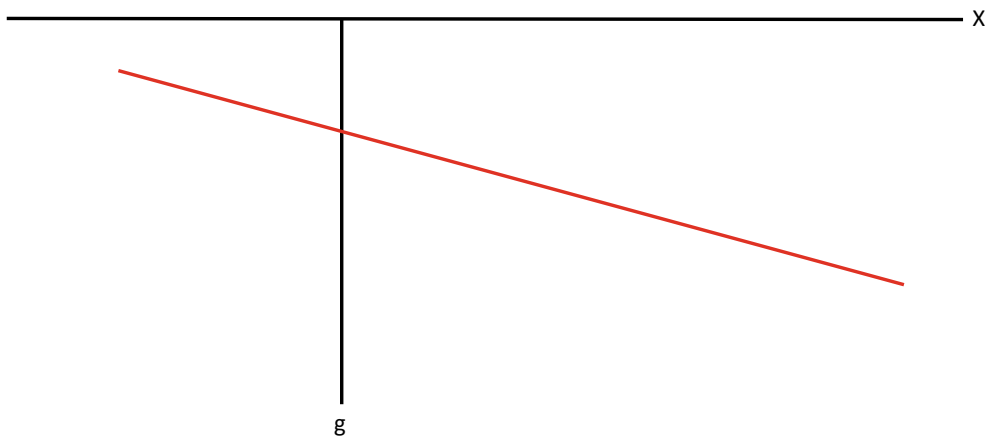

Fig. 12.1 Growth as a function of trade surplus. Source Authors' own presentation 


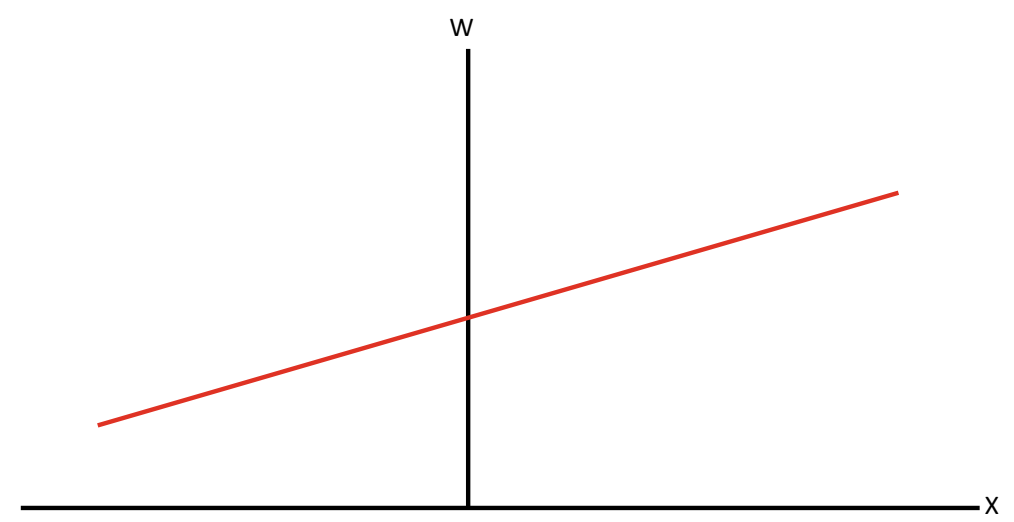

Fig. 12.2 Trade surplus as a function of the exchange rate. Source Authors' own presentation

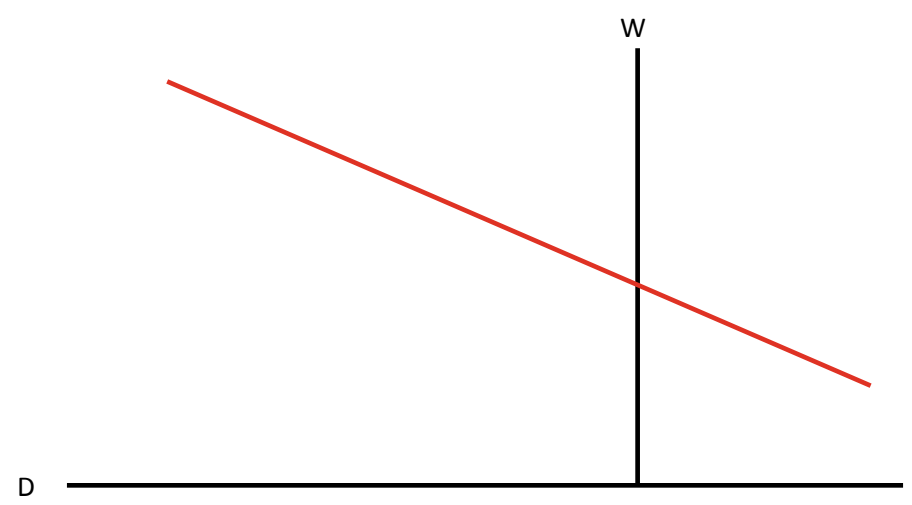

Fig. 12.3 Northern public debt as a function of the exchange rate. Source Authors' own presentation

more public debt must take over the role of satisfying the level of desired wealth. Figure 12.3 shows this relationship.

Note that public debt $D$ is plotted from right to left: the further left, the greater the public debt. As already noted, the public debt in question is that required for full employment in the North.

We thus have three causal relationships, which we can also express as the functions $\mathrm{f}, \mathrm{g}$ and $\mathrm{h}$. After each formula, we indicate the theoretical source of the causal relationship it encapsulates. 
$g=g(X)$ : "Learning from customers" (F. List).

$X=f(w)$ : Neoclassical theory.

$D=h(w)$ : The theory of the present book.

These three equations contain four variables. Economic policy can now set the value of one of the four variables, in order to generate the values of the other three. We assume that it uses central bank interventions to determine the real exchange rate $w$. We will discuss how this is done a few sentences further on. If the exchange rate $w$ is given, then market processes will give rise to a trade surplus $X$ and this, in turn, will result in a Southern growth rate $g$. Furthermore, the North adjusts its public debt $D$ to the exchange rate, so that there is full employment in the North.

Figure 12.4 provides a graphical representation of this reasoning. We choose two exchange rates to compare their effects. The low exchange rate corresponds to the green line connecting the other three variables. The high exchange rate corresponds to the blue line connecting the other three variables.

The graph in Fig. 12.4 is nothing other than a composite image of the three previous graphs. The four variables are depicted on the four lines starting from point zero. The exchange rate $w$ is plotted on the "northern line" that goes upward, the South's trade surplus $X$ on the "eastern line," the South's growth rate $g$ on the "southern line," and North's full-employment public debt $D$ on the "western line."

We have drawn the graph so that it reflects our theory of the negative natural rate of interest. In Chaps. 2-8 of the present book, we show that the North has a negative natural rate. The model of a closed economy that we have used for the

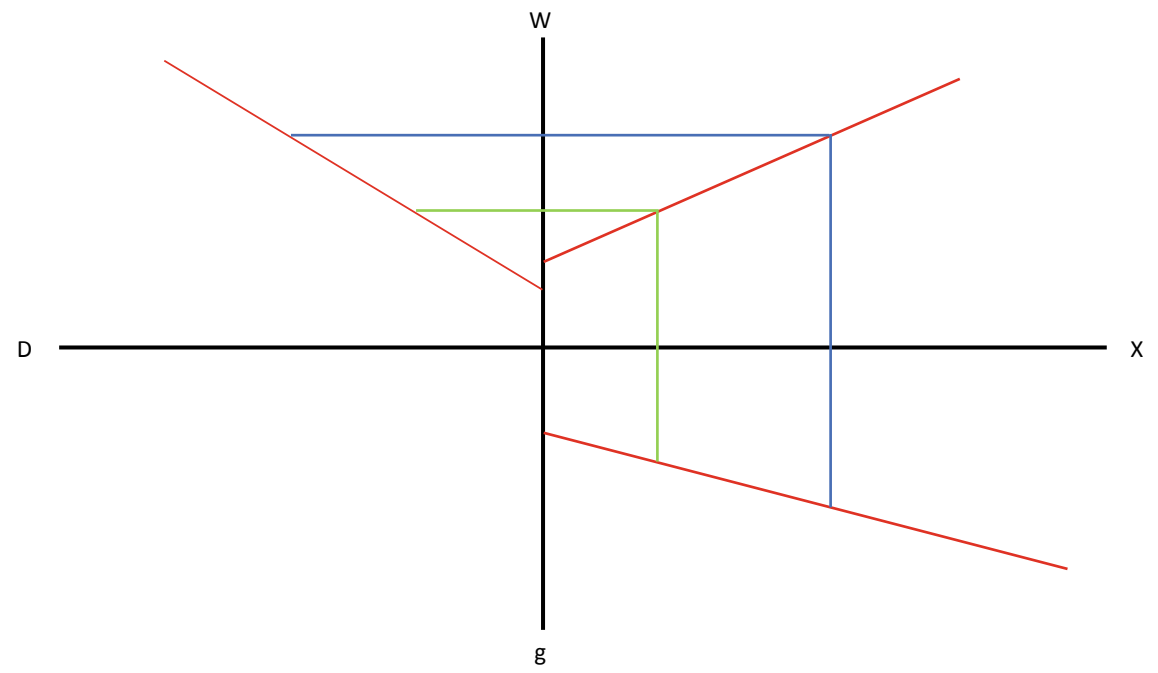

Fig. 12.4 Two alternatives: blue: high $w$; green: lower w. Source Authors' own presentation 
North corresponds to a Southern trade surplus of zero. We can see from the graph that at an exchange rate that generates a Southern trade surplus of zero, the North's full employment public debt is positive. This reflects our thesis that with stable prices the interest rate cannot fall to the level of the negative natural rate.

We will now briefly discuss the technique for setting the exchange rate. The two central banks have to agree on the exchange rate. They can then steer the exchange rate toward the target value by each of them buying or selling the other currency. Moreover, by announcing the target exchange rate, they can also get other market actors to steer toward this target rate by way of their portfolio decisions. What is crucial is the credibility of the announcement that the two central banks are in agreement about the rate. If the announcement is credible, then the "forward guidance" on the part of the two banks should work. Assuming that the full-employment equilibrium interest rate in the North is approximately zero, monetary and fiscal policy have to be coordinated for the goals of price stability and high employment to be achieved simultaneously. "High employment" or "full employment" is a level of employment that leads to neither inflationary nor deflationary wage pressures. Friedman (1968) coined the term "natural rate of unemployment" for the unemployment that remains.

The thought experiment developed here is not a "model" that can be tested econometrically. Such a model would have to depict a dynamic, i.e., development over time, in order then to be tested using available macroeconomic time series. Our thought experiment belongs rather to the tradition of equilibrium analysis, as it has been practiced for centuries in economic theory. This tradition includes the works of Francois Quesnay, Adam Smith, David Ricardo, Alfred Marshall, Léon Walras, and John Maynard Keynes - and, of course, Paul Samuelson's neoclassical synthesis.

John Hicks's interpretation of Keynes's General Theory using a model with six variables (Hicks 1937) is a similar attempt to represent an economic idea by means of an equilibrium model that is as simple as possible. Like the thought experiment developed here, Hicks's model contained three behavioral equations: the consumption function, the investment function and the demand function for liquidity. The price level and its changes are not explicitly modeled in either the Hicks model of the Keynesian theory or the thought experiment developed here. The Hicks model has to be understood as a model of underemployment, whereby, however, the possibility of a deflationary process is not taken into consideration. Thus, the best way of reading the Hicks model is that it presupposes a stable price level. Price stability is likewise assumed in the thought experiment presented here.

This experiment only makes sense, if, as we showed earlier, the natural interest rate is negative. As long as we are in the "Friedman world," about which we have spoken in the previous two chapters, it is the sole responsibility of the central bank to ensure that there is simultaneously price stability and high employment. The function $D=h(w)$ that we have stipulated here makes no sense in the Friedman world. For as long as the full-employment real interest rate remains positive, it is up to the nation state to decide how high it wants its public debt to be. The domestic 
interest rate level corresponding to full employment will, however, be influenced by external factors: for example, by the exchange rate.

As one of its key findings, our thought experiment shows that a higher exchange rate of the dollar (= a lower exchange rate of the rupee) is advantageous for both countries: the North and the South. This will be immediately obvious for the South. Inasmuch as the South can make better use of the learning potential of exports when the exchange rate of its own currency is lower, a lower exchange rate also corresponds to higher growth. At the same time, more jobs will be created in the South, so that the incentives for migration to the North will be lower. But the North also benefits. Full employment will be brought about through the required level of public debt. At a higher exchange rate of the dollar, the terms of trade improve for the North. Hence, there is also a positive effect on Northern prosperity. In addition, at a real interest rate of zero and a real growth rate that is to be set as positive, public expenditure can be financed with lower tax rates. For at a growth rate $g$ that is to be taken as given, the steady-state primary deficit that is consistent with stability is higher, the higher the public debt ratio $D$. At an interest rate of zero, the household income $\hat{w}=w(1-(r-g) D)^{1}$, which was defined in the chapter on the natural rate of interest, is, after all, given by $\hat{w}=w(1+g D)$. The primary deficit per labor year that is consistent with stability is precisely $w g D$. Since taxes have a distorting effect that increases disproportionately with increasing tax rates, the prosperity gained per worker is even greater than $w g D$. The decline in the incentive to immigrate to the North that is associated with the higher Southern growth is also good for the North. The last few years have shown the vehemence with which a majority in the North bridles at immigration from the South.

If we consider the two economies as a whole, both thus benefit from raising the exchange rate. As long as we ignore the distributive effects within the two countries, the latter thus brings about a "Pareto improvement." It is to these distributive effects that we turn now.

\subsection{The Utopia of a Demand-Oriented Growth Strategy for Developing Countries}

In the previous section, we went through a thought experiment that we could call a demand-oriented growth strategy for developing countries. According to our analysis, it benefits not only the South, but also the North. It is, nonetheless, utopian. Northern thinking runs along different lines. The Northern public associates helping the South with "development aid." This has long consisted primarily of financial assistance. As concerns cash flows, the latter is, however, exactly the opposite of the demand-oriented growth strategy for poorer countries that we have presented here. The goals of financial assistance to poorer countries have been internationally agreed upon, but never achieved. Were they to be achieved, then this

\footnotetext{
${ }^{1}$ Here and in the following few lines $\omega$ is the "wage rate" and not the rate of exchange
} 
assistance would bring about a reduction of around three-quarters of a percent of Northern GDP in the Southern current account. In keeping with the thought experiment of the preceding section, this means that the growth of developing countries is diminished by this financial assistance. But numerous well-intended charitable campaigns on behalf of poor countries are also counterproductive. A prime example of this are donations of old clothes, which, in reality, make it more difficult for the recipient countries to develop their own garment industry.

Of course, there are also numerous well-organized investment projects, such as those of the World Bank, which contribute to the prosperityof the recipient countries. But this project funding predominantly consists of repayable loans. Moreover, it demands a certain discipline from the recipient country, in the sense of rational, economically efficient use of scarce monetary resources. Its utility consists less in funds being temporarily made available as in the recipient countries learning how businesses can be economically efficient and how to select suitable investment projects that are worth financing.

By contrast, development aid - which is, above all, also a form of aid for the donor country's exports - is problematic from the point of view of the recipient country's growth. Politically, however, it is much easier to get support for it in the donor country. The political economy of development aid is a kind of subform of the political economy of protectionism. One "does good" in a poor, foreign country and thereby creates sales outlets for one's own industry (Easterly 2006). China's Silk Road project is a gigantic example.

Even if the demand-oriented growth strategy for the South that we have sketched out would increase prosperityin the North, it would also be associated with massive restructuring. In a transitional period, of course, numerous jobs would be destroyed in the North: especially in export-oriented industries and industries that are exposed to competition from imports. On the other hand, more jobs would come into being in other industries. In a "Keynes world," however, the jobs argument is paramount for voters. There would be strong opposition to shifting to such a strategy. For the jobs being lost are concrete - they are visible in the present-whereas the jobs that will replace them are abstract and for the moment intangible. Moreover, the champions of the status quo would be eager to seize on the argument that these new jobs are to be created through increased public debt: that it is a matter of replacing already existing jobs by "jobs purchased on credit."

In a sense, it is because its high current account deficit is practically a structural feature that the USA has up to now pursued a policy of promoting other countries' growth. Since, moreover, it is the country that controls the global reference currency, it has never experienced balance of payments problems. The world has been happy to provide the means for financing the current account deficit by exporting capital to the USA. At the same time, these current account deficits also contributed to the fact that China could successfully launch and pursue its export-oriented growth strategy. But the election of Donald Trump as president in 2016 is a signal that such a demand-oriented promotion of other countries' growth no longer reflects the will of the American electorate. And, as discussed already in Chap. 10, this "new protectionism" will also be pursued by his successor Joe Biden. 
Our analysis of the political economy of international economic policy in Chap. 10 attributes the worldwide resurgence of protectionism precisely to the phenomenon of the negative natural rate of interest, which, as shown in the present chapter using a two-country model, offers the opportunity to pursue a strategy of demand-oriented growth promotion.

There is no way of resolving this paradox in the short to medium term. Now and for the foreseeable future, there is neither the awareness nor the political will required for a restructuring that would take us in the direction of a demand-oriented growth strategy for the developing countries.

But it is worth at least fighting for the principle of free trade - also for the benefit of the poor countries. For there are numerous barriers to exports from the poor countries to the rich ones.

\subsection{A Utopian Look into the Future}

The digitalization of all human life, along with the rise of artificial intelligence, is perceived as an opportunity, but also as a threat. Many people fear that work is "disappearing." But precisely from the perspective of international competition, the promotion of restructuring toward more digitalization, and, in particular, also artificial intelligence, is being called for. If it really were the case that these technical developments take work away from global society, then we would have to regard promoting them in the interest of national competitiveness as a "beggar thy neighbor" policy like imposing import tariffs. We thus believe that it is important to be able to show conclusively that work in the North is not disappearing.

Our theory of the negative natural rate of interest rate and the reinterpretation of public debt based on it can help us here. In Sect. 12.2, we pointed out that the end of capital scarcity, i.e., the negative natural rate of interest, should not be confused with an end to the scarcity of time. The latter remains. Thanks to modern means of communication, the potential for beneficial interaction is so great that one's own time is, more than ever, the limiting factor. Hence, a reduction in the share of the labor time devoted to wage-earning in a lifetime cannot be regarded as any catastrophe, so long as, despite this reduction, the monetary means are still available to satisfy the individual's consumption wants.

Taken to an - unrealistic - extreme, the productivity gains from digitalization could be exclusively used to reduce wage-oriented labor in the North, so that there would no longer be any real growth of the economy. This would then be in the spirit of the picture that Marx and Engels paint of communist society, in which: “... society regulates the general production and thus makes it possible for me to do one thing today and another tomorrow, to hunt in the morning, fish in the afternoon, rear cattle in the evening, criticise after dinner, just as I have a mind, without ever becoming hunter, fisherman, herdsman or critic" (Marx and Engels 1970, 1846], p. 53). But then there is also no longer any need for detailed regulation of pro- 
duction by the state, since people, whether for money or because they simply want to be helpful to others, do work voluntarily within the framework of the division of labor.

We do not have to ponder today what exactly such a society would look like or how large the role of exchange via money would still be in it. As a medium of exchange that balances supply and demand amidst a great variety of goods, it will always be superior to detailed state planning. Nonetheless, the share of goods that are altruistically produced (as opposed to being produced for profit) may, of course, be higher than it is today. Today, there are still an enormous amount of activities for which there is demand, but whose performance is associated with "onerous" labor. These activities are carried out in exchange for monetary compensation and are thus relatively expensive - to a not insignificant extent, also because the state is essentially financed by taxation of the market-mediated division of labor. This is why, in the spirit of the notion of "induced technical change," the potential of digitalization and of artificial intelligence will be directed, above all, at rationalizing these sorts of activities: so that the technical change in question will be such as to lower the disutility of labor.

If this hypothesis is correct, then another side of technical progress through digitalization will be that it tends to rationalize, in particular, low-skilled jobs out of existence. For there is a tight negative correlation between the level of qualifications that is required for an activity and the "onerousness" that is associated with it. Thus, technical change that rationalizes onerous labor out of existence would appear to be a generator of unemployment among the unskilled.

This makes the goal of full employment all the more important. The elimination of low-skilled jobs in favor of the creation of skilled jobs should be carried out in such a way that persons with limited qualifications do not fall into the abyss of unemployment. But this requires a flexible fiscal policy, which, in further developing macromanagement of a Keynesian inspiration, does not shy away from taking on public debt at what we can expect to be persistently low interest rates.

\subsection{The Gist of the Argument}

In this chapter, we have connected the elfin utopia of a world without onerous labor and a further development of Friedrich List's theory. Instead of using the latter to justify a policy of "educational" tariffs, we have reshaped it, in light of the experience of East Asia and especially China, into an argument for free trade-and especially for promoting exports from poor countries to rich ones. By way of List's idea of learning from technically and organizationally superior customers, this should in turn promote economic growth in the developing countries. In order for this strategy to be compatible with full employment in the rich countries, we have to find a different attitude toward public debt than that which has prevailed up to now. For in this context, public debt increases the prosperity of the rich countries. In a sense, onerous labor is "outsourced" to the South and replaced by less onerous labor 
in the North. We thus come a step closer to Marx and Engel's idyllic conception of a communist society without onerous work.

But, for the moment, this is all just a utopia.

\section{References}

Bernanke, Ben. 2005. The global saving glut and the U.S. current account deficit. Speech 77. Washington (D.C.): Board of Governors of the Federal Reserve System.

Easterly, William Russell. 2006. The White Man's Burden: Why the West's Efforts to Aid the Rest Have done so Much Ill, and so Little Good. London: Penguin Press.

Friedman, Milton. 1968. The Role of Monetary Policy. American Economic Review 58 (1): 1-17.

Hamann, Brigitte. 1978. Rudolf - Kronprinz und Rebell. Wien: Amalthea.

Hicks, John R. 1937. Mr. Keynes and the Classics - A Suggested Interpretation. Econometrica 5 (2): $147-159$.

Kopisch, August. 1998 [1836]. The Elves of Cologne, trans. Anthea Bell. New York: North-South Books.

List, Friedrich. 1841. Das nationale System der politischen Ökonomie. Stuttgart: Cotta.

Marx, Karl and Friedrich Engels. 1970 [1846]. The German Ideology, ed. C. J. Arthur. New York: International.

Open Access This chapter is licensed under the terms of the Creative Commons Attribution 4.0 International License (http://creativecommons.org/licenses/by/4.0/), which permits use, sharing, adaptation, distribution and reproduction in any medium or format, as long as you give appropriate credit to the original author(s) and the source, provide a link to the Creative Commons license and indicate if changes were made.

The images or other third party material in this chapter are included in the chapter's Creative Commons license, unless indicated otherwise in a credit line to the material. If material is not included in the chapter's Creative Commons license and your intended use is not permitted by statutory regulation or exceeds the permitted use, you will need to obtain permission directly from the copyright holder. 